\title{
Difficulties of Implementation of Primary English Education in the Republic of Kazakhstan: Language Teachers' Views
}

\author{
Bakhytgul A. Zhetpisbayeva ${ }^{1} \&$ Tatyana Y. Shelestova ${ }^{1}$ \\ ${ }^{1}$ Academician Y. A. Buketov Karaganda State University, Karaganda, Kazakhstan \\ Correspondence: Tatyana Y. Shelestova, Academician Y. A. Buketov Karaganda State University, 28, \\ Universitetskaya St., Karaganda, 100028, Kazakhstan. E-mail: shelestova2009@mail.ru
}

Received: June 15, 2015 Accepted: July 10, 2015 Online Published: September 21, 2015

doi:10.5539/res.v7n12p13 URL: http://dx.doi.org/10.5539/res.v7n12p13

\begin{abstract}
In 2012 the Ministry of Education and Science of the Republic of Kazakhstan has developed State Educational Standards for primary education and curriculum for teaching English to grades 1-4 and the age for English language learning (ELL) has been lowered to 6-7 years of age. This research aims to investigate the extent to which teachers are ready in their teaching in primary schools, how it should be conducted with young learners (YL), and finally what problems of implementation and organization of English Language Teaching (ELT) in primary schools in Kazakhstan language teachers faced with. The data for the study is gathered from 105 English teachers working in different primary schools. The study revealed that along with the positive experience some schools and teachers have had in teaching English languages to young learners (ELYL) from the ${ }^{\text {st }}$ grade, most of them have not yet made a transition to the system organization of teaching foreign languages in the primary school.
\end{abstract}

Keywords: young learners, English language teaching, primary school, education system, multilingual education

\section{Introduction}

The new social and economic conditions of development of the Kazakh society, the processes of economic globalization, integration in various spheres of life require learning a foreign language as a means of cross-cultural, business and personal communication.

Kazakhstan aims becoming a society knowledgeable in all spheres of life. The importance of knowing a foreign language as a tool for access to sources of information is unquestionable. Therefore, students should feel prepared to communicate in such a system.

Presently, computer science, economics, law and foreign languages are considered to be the high-priority fields of modern education in Kazakhstan. A foreign language, English in particular, is a leading discipline today, as in the conditions of active development of the international communication the value of a school or college graduate in the labor market is highly determined by his/her level of the foreign language proficiency.

Today it is possible to say with high level of confidence that teaching English is becoming an integral part of the primary stage of learning in local and foreign schools.

In the Kazakhstan education system special attention is paid to pre-school and primary school education and training, where fundamental values and background knowledge are formed. It has been proven by science that early learning is effective enough to master foreign languages. This scientific fact has been considered in the State Program of Education Development in the Republic of Kazakhstan for the period of 2011-2020. The program aims at bringing together the existing practice of Teaching English to Young Learners (TEYL) and international experience in the same field. Also, the program ensures the continuity of foreign language education and consistency of educational programs; it determines the high quality and efficiency of a multilingual person development as one of the most significant factors in the development of the country intellectual potential (SP of DE RK, 2010).

A major curriculum innovation project was designed to make changes in the nation's ELT practices at all levels of education so as to promote the teaching of English and to introduce the concept of communicative approach into ELT (Kırkgöz, 2005, 2007). 
In accordance with the strategic plan of the Ministry of Education and Science of the Republic of Kazakhstan (MES of RK) for the years 2011-2015, in 2012 there were developed State Educational Standards (SES) for primary education and curriculum for teaching English to grades 1-4; the pilot projects were started to teach some school subjects in English. According to the new curriculum the starting age for English language learning (ELL) is lowered to 6 years of age (first grade).

\section{Discussion}

The idea of the state policy to develop a multilingual personality is implemented in pilot projects at different levels (schools, colleges, universities) where students are taught in three languages. Excellent results have been achieved by the Kazakh-Turkish lyceum; multilingual education has been successfully implemented in the Nazarbayev Intellectual Schools with the help of professionally trained teaching staff, efficient teaching technologies and the desire of students to study in three languages.

Curriculum changes and renovations not only affect the learners but also teachers and teacher training process as well (Gürsoy, Korkmaz, \& Damar, 2013). The major problem arising for the school practice in the first place is the absence or a small number of qualified and creative teachers; in the second place, it is the lack of methodological and teaching materials (insufficient number of special training manuals and programs for the study of subjects in Kazakh, Russian and English).

The need that must be immediately addressed at the state level is to promote the development of multilingual education in schools, provide the conditions for the teachers to cooperate and share their experience on multilingual teaching, create a database of educational programs and manuals for multilingual education. In its turn, such an urgent need requires the regulatory and methodological support for learning English from Grade 1.

In relation to a foreign language as a school subject, the development of SES for primary education was of fundamental importance as a foreign language has been given a new status: it has been included as a compulsory subject in the state curriculum in the field of "Language and Literature" from the first grade. This emphasizes the importance of all three languages (Kazakh, Russian and English) in the development and education of students as well as the importance of language development as the foundation of all education.

The SES project has not been approved yet, as there is no agreement in the scientific community regarding the age for ELL. There has been a positive experience of ELT to the second grade students, i.e. the learners aged 8-9 years. The majority of researchers agree that the best time to start learning foreign languages is the preschool and early school age, i.e, 5-8 years. Two assumptions for "younger the better" philosophy is that younger children find learning FL easier (Nunan, 2003) and that longer the duration of language education higher the proficiency by the time children graduate from school (Enever \& Moon, 2009).

In Europe compulsory second language (L2) learning starts from age 6-7. The EU strongly encourages the governments to start L2 as early as pre-school or primary school (Enever \& Moon, 2009). According to the "Nuremberg Recommendations" (NR, 2010), the results of international studies reveal that TEYL live up to expectations from it. According to Johnstone (2009) an early start at around age five has several advantages: First of all, younger children can acquire the sound system of L2 easier than older children. Moreover, YLs have lower affective filter, thus are less anxious. Younger children will have more time to learn L2 in the long run. Various acquisitional processes can be used in time. For example, at the younger ages children depend on their intuitions but later on their analytical thinking develops as they move forward in Piaget's cognitive developmental stages. Finally, Johnstone (2009) argues that cognitive, linguistic, and socio-emotional skills as well as their awareness on multiculturalism enable children to develop an identity that is going to be different if they start at a later stage. These differences arise from the differences between children and adults (Gürsoy, 2010). Children bring in some natural skills and characteristics to the classroom (Gürsoy, 2010; Halliwell, 1992). Most importantly, unlike adults, they don't have a reason for learning another language when they can perfectly communicate in their mother tongue (see Gürsoy, 2010; Gürsoy, 2012a; Halliwell, 1992; Moon, 2000).

The system of preschool education, as well as the modern primary school, undergoes a qualitative transformation and renewal. The analysis of the pre-school education in the country suggests introduction of trilingual educational system (Kazakh, Russian, English) in the preschool system. Thus, the state and society consider the language learning of primary school children as a value. In our opinion, it is important to ensure the continuity of language education at all levels of pre-school and school education; it is important to direct language learning towards the implementation of the future goals of personal development, namely, the growth of the average level of education of country citizens, increasing their general cultural level, the formation of their readiness for international and intercultural cooperation. 
We believe that the process of ELL starting from the first grade is going to be successful as long as learning begins before the age of eight; the process of ELT, its content and technology has been organically included in the curriculum of the primary school; ELT is carried out by experienced and qualified teachers.

This article considers the problem of readiness of schools for the organization of educational process and readiness of staff to teach English according to the SES project; there is also considered the problem of providing schools with didactic and teaching materials on the subject "English" in the framework of the State Program for Education Development of the Republic of Kazakhstan 2011-2020.

\section{Materials and Methods}

To address these issues in the study there were used different sources and scientific methods: the study of literature, interviews and questionnaires for the teachers who teach English in the primary school.

Our preliminary semistructured interview with school teachers allowed us to obtain a better understanding of the organization of educational process in the primary school on the subject "English" and became the basis for the preparation of the questionnaire.

105 English teachers working in primary schools in Kazakhstan took part in the questionnaire. The average work experience of the respondents in these organizations was more than twelve years. The questionnaire was conducted in general education schools, where the pilot project on early learning of English (starting from grade two) had not been previously conducted, as well as in gymnasium schools, where there had been some experience in early learning of English.

To conduct the questionnaire, we prepared the questions consisting of two units: a) staffing on the subject "English"; b) the organization of educational process for the subject "English". The first unit consisted of questions on professional development of the teachers, including the questions on how ready the teachers are to teach English from the first grade. The second set of questions aimed at identifying the availability of resources required for the organization of educational process for the subject of "English" (availability of a language laboratory, an individual room for teaching the subject, teaching materials). Its goal was also to determine whether these resources are used efficiently. In this study, we sought to identify what difficulties arise for the primary school language teachers as well as to find out what teachers require in order to improve the educational process in the primary school to conduct efficient English lessons.

The methods of data collection in this study consisted of a blend of qualitative techniques chosen to help us capture how these teachers made sense of their experiences (Bogdan \& Biklen, 2003; Denzin \& Lincoln, 2005).

\section{Results}

The results of the first unit revealed the percentage of teachers who received the advanced training course on teaching English to young learners.

It should be noted that several factors make the modernization of primary school education complicated. One of such factors is a critical shortage of teachers familiar with the methods for teaching English to young learners.

Figure 1 below presents the information on how teachers used different resources for their professional development. 


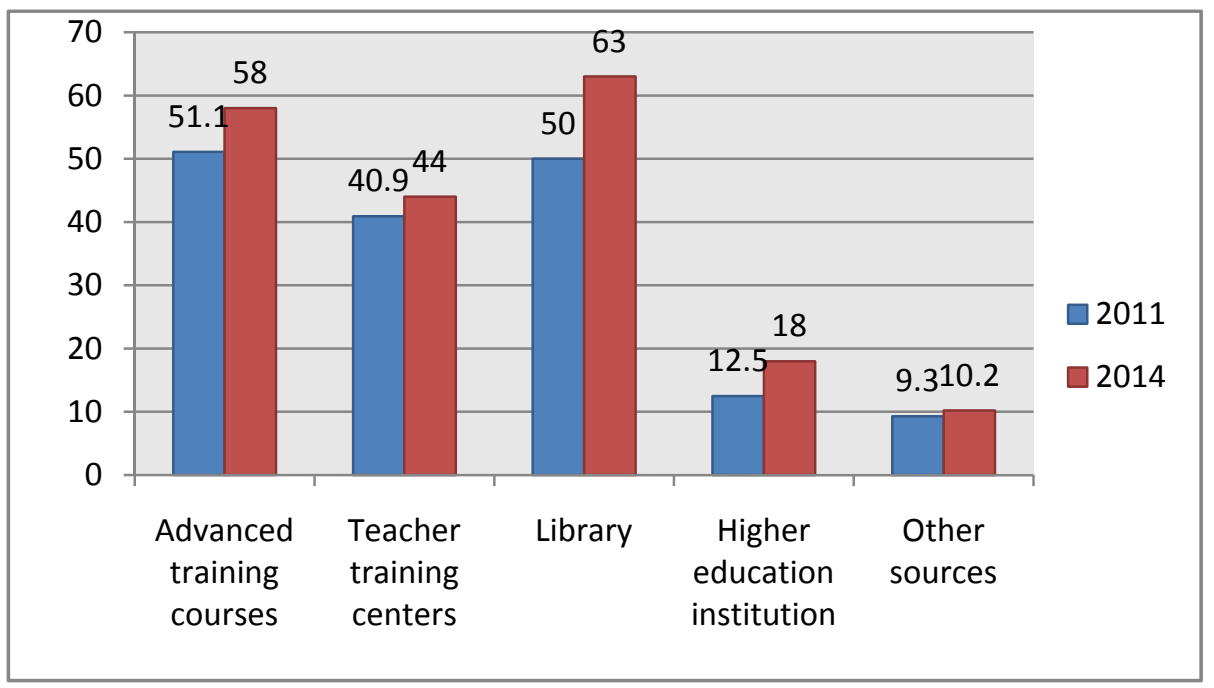

Figure 1. The sources for teachers' professional development (\%)

Thus, despite the improvement compared to the year 2011, today about half of all foreign language teachers working in primary schools are not able to take advanced training courses timely, which has a general negative impact on the level of teaching the foreign language to young learners.

The study also revealed that the teachers have low levels of intrinsic motivation for self-improvement: training mostly takes place because of the school administration order, and not by the teachers' own initiative.

The reasons for this condition are as follows:

- Shortage of state (and personal) financial resources for professional development of the teachers;

- Insufficient motivation of the teachers to improve their professional level (both intellectual and material).

These conditions define an obvious need for the creation of an optimal model of professional retraining and advanced training of foreign language teachers taking into account the specifics of teaching in primary schools. Therefore, it becomes a goal of state importance to find new resources for training of the teachers to prepare them for a new professional activity such as TEYL.

Teaching is going to be more efficient and will ensure a high level of achievement of students in the foreign language study, if the teachers are provided with modern teaching materials (programs, curriculum and instructional kits (CIK), methodological literature, etc.).

Availability of quality course-books and teaching materials used in the educational process in accordance with SES of primary education is one of the criteria for readiness of educational institutions to perform educational activities. Therefore, the content of the program and curriculum and instructional kit (CIK) is a very significant aspect, as young learners are going to use them to obtain basic knowledge and master the material. Their quality will determine how quickly and easily a child will be involved in the process of learning the foreign language, and what knowledge s/he is going to obtain before $\mathrm{s} / \mathrm{he}$ gets to the high school.

Following curriculum and instructional kits are offered and widely used for teaching English to primary school students: Family and Friends (published by Oxford University Press), Primary Colors (published by Cambridge University Press), English (published by Almatykytap).

CIK mentioned above include not only a course- book, but also a teacher's book, a workbook, audio material to work in the classroom and at home, and other educational materials. These CIK have been recommended by the Ministry of Education of Kazakhstan as they were developed in accordance with modern requirements for teaching foreign languages in primary schools. Some of such requirements are the use of Kazakhstan's content in the course -books, correspondence of the concepts presented in the materials with the scientific knowledge, grading of the information according to the level and age of the students, logical relationship with other sections and stages of mastering the subject; apprehensible presentation of information for the learners.

The CIK mentioned above have been included in the pilot project on learning a foreign language from the first grade in order to check how apprehensible and adequate they are for the learners, how the learner-centered 
approach is applied, and how they help to increase young learners' motivation to study a foreign language.

We have verified some of the CIK against the modern requirements. CIK analysis led to the conclusion that not all teaching materials, developed and recommended by the MES of the Republic of Kazakhstan, are fully available in schools and developed in accordance with the Common European Framework of Reference for Languages. Not all the teachers are fully provided with the methodological aids, and not all the students are provided with the course-books and workbooks. There is no required basis of the state language to teach English (quality dictionaries, course-books, translated literature, the teachers of English for the schools with the state language of instruction).

The information on availability of course-books and teaching materials for students and teachers is presented in Figure 2.

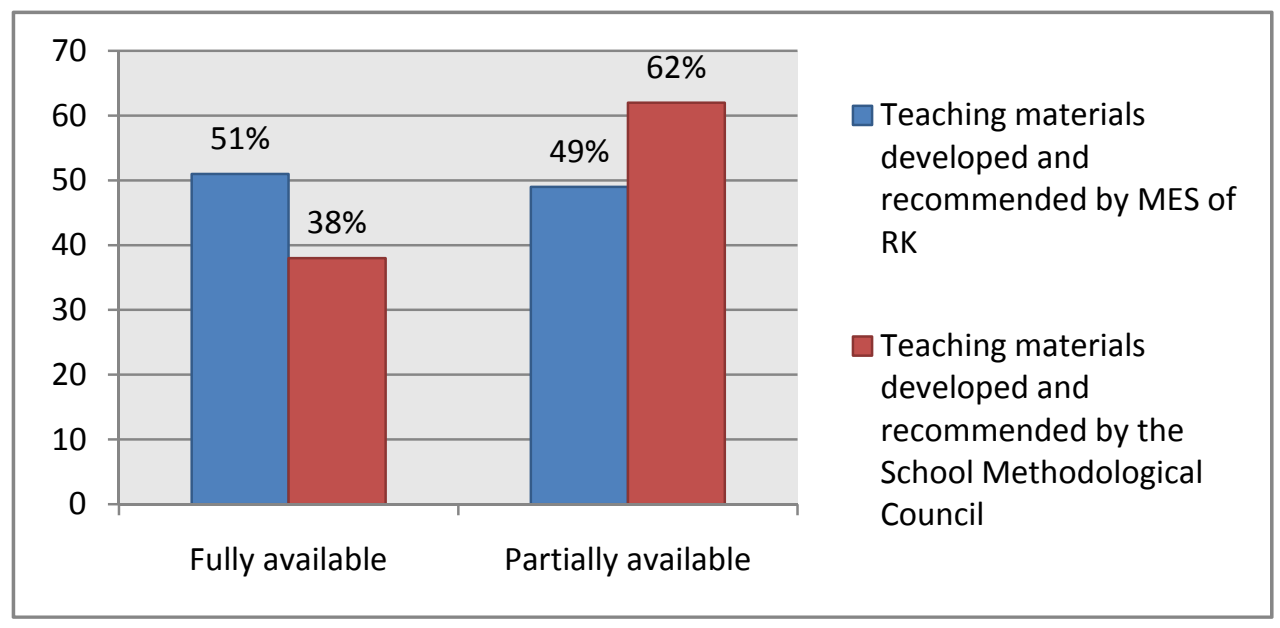

Figure 2. Availability of teaching materials for the teachers $(\%)$

In our opinion, the most important requirements to work out textbooks are the contents, compliance of information and logic of tasks to young learners' age and cognition with account of national (Kazakhstan) content; the accounting of the young learners' knowledge; availability of tasks for the organization of independent young learners' work, repetition and fixing, self-checking and a self-assessment; pictures capable to interest pupils; continuity in contents of textbooks.

The result of this study demonstrates compliance of CIK with the modern requirements presented in Figure 3.

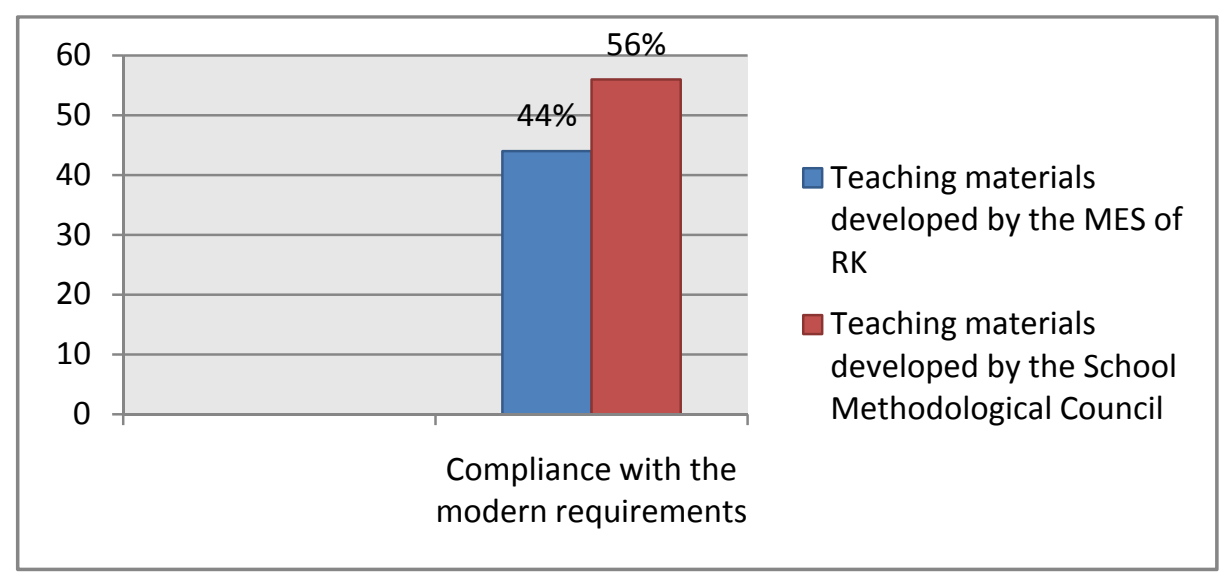

Figure 3. Compliance of CIK with modern requirements (\%) 
These data indicate that the teachers are not fully provided with the materials, and only some of materials meet the modern requirements. The lack of teaching materials, that systematically and purposefully meet the modern objectives, content and technology of early learning the language, makes the process of language teaching and professional teacher training process not efficient enough.

The availability of the teaching guides helps to increase young learners' achievements in the foreign language learning, but it is not the only factor. The teaching methods used by the teachers have a significant impact on the young learners' results (Table 1).

Table 1. The use of teaching methods (\%)

\begin{tabular}{|c|c|c|c|c|}
\hline Teaching methods & Often & Randomly & Seldom & Never \\
\hline Verbal methods & 53.4 & 23.9 & 8.0 & - \\
\hline Visual methods & 70.5 & 20.5 & 1.1 & - \\
\hline Error correction & 62.5 & 25.0 & 2.3 & 1.1 \\
\hline $\begin{array}{l}\text { Creative tasks and tasks of higher } \\
\text { complexity }\end{array}$ & 33.4 & 38.6 & 18.2 & - \\
\hline
\end{tabular}

The teachers who advocate an early start emphasize the use of appropriate teaching techniques with children to reach the desired outcomes (Gürsoy, Korkmaz, \& Damar, 2013). These techniques involve activity-based teaching $(\mathrm{NR}, 2010)$ during which children learn by developing experiences with the language. Children learn indirectly as they focus on meaning rather than form (Gürsoy, 2012b; Moon, 2000). At the foreign lessons primary school teachers mostly use visual methods and techniques. Practical methods implying creative tasks are rarely used. The creative approach is connected with certain difficulties such as stating the assignments, time consumed for their fulfillment and assessment. Meanwhile, the data may mean that the teachers do not take into consideration the learners' "zone of proximal development" (Vygotskiy, 1978); therefore, they do not always plan and consider the developing objectives for their lessons.

Meanwhile, it is clearly stated in pedagogy that the learning of the material by learners at the lessons depends on the teaching methods chosen. There is known the learning ability pyramid that demonstrates how information is taken in depending on the method of educational process organization: the teacher's monologue $-5 \%$ efficiency, independent reading - $10 \%$; whereas, practice and interaction (a student teaches a student) provides $75 \%$ and $90 \%$ respectively. efficiency for learning a material.

The use of various tools in teaching foreign languages enables better teaching and higher achievements by the learners. The data on the use of teaching tools by the primary school teachers at the foreign language lessons are given in Table 2.

Table 2. The use of teaching tools in the modern practice (\%)

\begin{tabular}{lllll}
\hline Teaching tools & Often & Randomly & Seldom & Never \\
\hline A blackboard & 95.5 & 1.1 & - & - \\
Posters/tables & 59.1 & 31.8 & 4.5 & - \\
Patterns/Models & 20.5 & 40.0 & 17.0 & 5.7 \\
Audio material & 2.3 & 15.9 & 22.7 & 27.3 \\
Video material & 1.1 & 8.0 & 15.9 & 42.0 \\
$\begin{array}{l}\text { Lessons taught with the use of multimedia } \\
\text { teaching tools }\end{array}$ & 2.3 & 33.0 & 42.0 & 8.0 \\
\hline
\end{tabular}

The analysis showed that the board and posters (tables) remain the main tool for teaching the foreign languages in primary schools.

The analysis showed that the foreign language teachers in primary schools are not fully provided with the methodological guides and use the limited number of teaching methods. There is observed a minor quality 
change in the use of teaching tools. Considering such conditions of teaching, it is impossible to expect high achievements of learners in the foreign language field.

There have been considered other factors leading to the decrease in the achievements of the learners studying the foreign language. The teachers believe that there are many reasons for the learners' low achievements in the study of the foreign language. Table 3 presents the teachers' opinions on the reasons.

Table 3. The reasons for young learners' low level of results in the study of the foreign language (\%)

\begin{tabular}{llll}
\hline The reasons for low results & $\begin{array}{l}\text { Significant } \\
\text { impact }\end{array}$ & $\begin{array}{l}\text { Moderate } \\
\text { impact }\end{array}$ & No impact \\
\hline $\begin{array}{l}\text { Non-availability of an individual room for the foreign } \\
\text { language study }\end{array}$ & 40.9 & 21.6 & 14.8 \\
$\begin{array}{l}\text { Non-availability of the resource base } \\
\text { No experience in teaching young learners }\end{array}$ & 49.7 & 33.0 & 14.8 \\
$\begin{array}{l}\text { Lack of methodology for teaching foreign languages in the } \\
\text { primary school }\end{array}$ & 53.4 & 31.8 & 5.7 \\
Non-availability of the teachers' own practical worksheets & 51.5 & 38.0 & 6.8 \\
$\begin{array}{l}\text { Non-availability of qualified guidance } \\
\text { Insufficient qualification of the teacher }\end{array}$ & 43.5 & 31.8 & 2.3 \\
$\begin{array}{l}\text { Inefficient goal-setting } \\
\text { Non-availability of the teaching materials complying with the } \\
\text { modern requirements }\end{array}$ & 65.9 & 30.7 & 13.6 \\
\hline
\end{tabular}

\section{Conclusion}

The teachers believe that the great negative impact on the learners' achievements is caused by the low qualification of the teacher $(65.9 \%)$ and non-availability of the teaching materials that meet the modern requirements $(69.3 \%)$.

More than $50 \%$ of the teachers state that the learners' low achievements in the study of the foreign language are caused by the lack of methodology for teaching English to young learners and little experience of most of the teachers in the same field.

Thus, along with the positive experience some school have had in teaching foreign languages to young learners, most schools have not yet made a transition to the system organization of teaching foreign languages in the primary school. Analysis of the problem in early learning enables to reveal the issues regarding the implementation of early language education in the Republic of Kazakhstan, namely:

- Non-availability of conditions required to organize early language learning;

- Lack of special methodology for teaching English to young learners with consideration of Kazakhstan content when it comes to learning three languages;

- Insufficient development of methodological and teaching materials containing the national content to organize a quality learning process in the primary school;

- Non-availability of local course-books published for individual levels of the English language proficiency;

- Non-availability of good adapted materials in English, English-Kazakh dictionaries and Kazakh literature texts in English published for the Kazakh schools;

Particular problems are the lack of staff teaching English to young learners and non-availability of conditions required for re-training and advanced development of the teachers.

The schools have been set the goal to train students in order to enable them to take part in cross-cultural communication in a foreign language and develop their foreign language proficiency independently. The complexity of the goal determines the content and the main directions of scientific and methodical search in this area. 


\section{References}

Bogdan, R. C., \& Biklen, S. K. (2003). Qualitative research for education: An introduction to theory and methods (4th ed.). Boston, MA: Allyn and Bacon.

Denzin, N. K., \& Lincoln, Y. S. (2005). Introduction: The discipline and practice of qualitative research. In N. K. Denzin, \& Y. S. Lincoln (Eds.), Handbook of qualitative research (3rd ed., pp. 1-41). Thousand Oaks, CA: Sage.

Enever, J., \& Moon, J. (2009). New global contexts for teaching primary ELT: Change and challenge. In J. Enever, J. Moon, \& U. Raman (Eds.), Young learner English language policy and implementation: International perspectives (pp. 5-21). Reading, UK: Garnet Publishing.

Gürsoy, E. (2010). Implementing environmental education to foreign language teaching to young learners. Educational Research, 1, 232-238.

Gürsoy, E. (2012a). Theme-based teaching: Environmental education. In E. Gürsoy, \& A. Arıkan (Eds.), Teaching English to young learners: An activity-based guide for prospective teachers. Ankara: Eğiten Kitap.

Gürsoy, E. (2012b). Music and Puppets. In E. Gürsoy, \& A. Arıkan (Eds.), Teaching English to young learners: An activity-based guide for prospective teachers. Ankara: Eğiten Kitap.

Gürsoy, E., Korkmaz, S. Ç., \& Damar, A. E. (2013). Foreign language teaching within 4+4+4 education system in Turkey: Language teachers' voice. Egitim Arastirmalari-Eurasian Journal of Educational Research, 53(A), 59-74.

Johnstone, R. (2009). An early start: What are the key conditions for generalized success? In J. Enever, J. Moon, \& U. Raman (Eds.), Young learner English language policy and implementation: International perspectives (pp. 31-41). Reading, UK: Garnet Publishing.

Kırkgöz, Y. (2005). English language teaching in Turkey: Challenges for the twenty-first century. In G. Braine (Ed.), Teaching English to the world: History, curriculum, and practice (pp. 159-175). Mahwah, NJ: Lawrence Erlbaum.

Kırkgöz, Y. (2007). English language teaching in Turkey: Policy changes and their implementations. RELC Journal, 38(2), 216-228. http://dx.doi.org/10.1177/0033688207079696

Moon, J. (2000). Children learning English. Oxford: Macmillan-Heinemann.

Nunan, D. (2003). The Impact of English as a Global Language on Educational Policies and Practices in the Asia-Pacific Region. TESOL Quarterly, 37(4), 589-597. http://dx.doi.org/10.2307/3588214

Nuremberg Recommendations on early foreign language learning. (2010). München: Goethe Institut.

Vygotsky, L. S. (1978). Mind in society. Cambridge, MA: Harvard University Press.

\section{Copyrights}

Copyright for this article is retained by the author(s), with first publication rights granted to the journal.

This is an open-access article distributed under the terms and conditions of the Creative Commons Attribution license (http://creativecommons.org/licenses/by/3.0/). 